\title{
THE EFFECT OF SUBMAXIMAL EXERCISE ON BLOOD CREATININE, UREA, TOTAL PROTEIN AND URIC ACID LEVELS OF TRAINED AND UNTRAINED SUBJECTS
}

\author{
Alina Gailiūniené ${ }^{1}$, Arvydas Stasiulis ${ }^{1}$, Jolanta Michailoviené $\dot{e}^{1,2}$ \\ Lithuanian Academy of Physical Education ${ }^{l}$, Clinical Hospital of Kaunas University of Medicine ${ }^{2}$, Kaunas, Lithuania
}

\begin{abstract}
Alina Gailiūnienè. Doctor Habilitated of Biomedical Sciences, Professor at the Department of Applied Physiology and Sport Medicine, the Member of the Senate of the Lithuanian Academy of Physical Education. Research interests — life span physiology, metabolism, problems of stress, fatigue and overtraining.
\end{abstract}

\begin{abstract}
There are numerous studies about exercise-induced sports hematuria, proteinuria, acute renal failure following a marathon (Steward, Posen, 1980; Poortmans et al., 2001; Ayca et al., 2006). But studies investigating the effects of exercise on blood indicators of renal function are quite few.

The aim of this study was to investigate the effects of submaximal veloergometric exercise on very important biochemical indicators of renal function - level nitrogen compounds in the blood. We investigated concentration of creatinine, urea, total protein and uric acid in venous blood samples before and after submaximal veloergometric exercise. Those nitrogen compounds were studied in three groups of subjects.

The study was performed with 10 trained (Group 1), 10 untrained subjects (Group 2) and 10 subjects with $I^{\circ}$ hipertensive status (Group 3). The age range was 20.5-21.3 years, weight $-71.8-77.3 \mathrm{~kg}$, height - $180-177 \mathrm{~cm}$. All subjects voluntered to participate in the study after providing written informed consent. The study was approved in accordance with the Declaration of Helsinki. Blood samples were collected before and after the submaximal veloergometric test into vacumtrainer tubes. Concentrations of creatinine, urea, total protein and uric acid in the serum were determined using Technicon Auto Analyzer ADVIA 1650 system.

All data were reported as mean \pm standard deviation (SD) unless otherwise specified, and statistical significance was recognized when $p \leq 0.05$.

No statistically significant difference was observed between pre- and post exercise blood creatinine, urea, total protein and uric acid mean levels of all group subjects. A marked exercise induced increase in blood creatinine and total protein concentrations was observed when the results of trained and untrained participants' parameter differences were compared after the exercise.

A significant $(p<0.05)$ exercise-induced increase in blood urea and total protein concentration was observed when the mean values of Group 1 and Group 2 before the exercise and parameters after the exercise were compared.

When blood creatinine, urea, total protein and uric acid levels were compared separately for the participants, it was observed that seven persons in Group 1 and three persons in Group 2 showed a marked exercise-induced increase in the blood nitrogen compounds level.

Research results suggest that 1) the testing exercise-induced statistically insignificant ( $p>0.05)$ increases in the blood parameters of nitrogen compounds (creatinine, urea, total protein and uric acid) could be due to the common phenomenon of the physical stress and catecholamine effects, 2) postexercise changes of blood nitrogen compounds were significant $(p<0.05)$ when the results of Group 1 with Group 2 participants were compared. The significant differences in metabolic responce in Group 1 and Group 2 participants probably reflect differences in work volume and intensity, and 3) further studies are needed to be performed on more subjects to evaluate exercise-specific effects on postexercise changes of blood nitrogen compounds in athletes and nonathletes.
\end{abstract}

Keywords: blood, creatinine, urea, total protein, uric acid.

\section{INTRODUCTION}

$\mathrm{T}$ esting in sport science is important for many reasons. The main purpose of testing is to establish the weakness of athletes and other individuals (Gore, 2000). Biochemical parameters and cardiac function is assessed according to a variety of indicators, including blood pressure response to exercise. Blood pressure is of particular importance, because hypertension is associated with an increased cardiac function and renal reaction. Elevated systolic or diastolic blood pressure 
is associated with risk of developing congestive heart function and kidney failure. The risk is nearly doubled when blood pressure is greater than $140 / 90 \mathrm{mmHg}$. Essential hypertension is the result of functional disturbances in blood volume, cardiac output, total peripheral resistance and regulation of kidney function (Ibsen et al., 2004, 2005). Many studies have reported an inverse relationship between the level of physical activity, fatigue and blood pressure (Curtis, Russel, 1997).

Recently it has been recognized (Ehrman et al., 2003) that exercise-induced minor renal dysfunction (i. e. reduced glomerular filtration rate) particularly in the trained subjects, is unduly understimated by relying only on the serume creatinine and urea values as the index of renal function.

The serum creatinine concentration depends not only on the glomerular filtration rate, but also on a number of confounding factors, particularly muscle mass, consumption of cooked meat, tubular secretion of creatinine and physical exercise load.

Nitrogen and its compounds and metabolites (creatinine, urea) are an important metabolic intermediate involved in many reactions within the body (Poortmans, Vanderstraeten, 1994). Nitrogen intermediate metabolites concentrations in the blood changed during to submaximal intensity exercise (e. g. up to $50 \%$ max ) (Bakonska-Pacon, Borkowski, 2003). Appreciable increases in creatinine, urea, total protein concentrations in the blood become evident at exercise intensities in the range of $70-75 \%$ max. Large increases, found in athletes, probably reflect a greater mass of muscle, that depletes ATP to greater extent than typically found in untrained persons.

Blood nitrogen intermediate metabolites concentrations in $\mathrm{I}^{\circ}$ hypertensive persons was greater than in trained and untrained persons (Terjung, Tullson, 1992). On the other hand, exercise can lead to increased accumulation of nitrogen intermediate metabolites in the blood if exercise is sufficiently intense and / or because of disordered renal function. Thus the observed blood nitrogen metabolites concentrations can vary depending on the exercise conditions (Poortmans et al., 2001). A clear dissociation between blood creatinine, urea and total protein concentrations can be easily demonstrated under conditions of their production and / or clearance from the blood in urine (Zambraski, 1990). In contrast to the defects described above, patients with $\mathrm{I}^{\mathrm{o}}$ type hypertension show an appreciable blood nitrogen metabolites accumula- tion with exercise, but little if any urea production. In addition, high levels of to uric acid (purine metabolite) are detected in blood when intensive adenine nucleotide degradation is observed, but not in all subjects. These responses are consonant with energy imbalance within the active muscle and are generally consistent with other known features of the disability energy metabolism (Terjung and Tullson, 1992).

Haemodynamic changes in the kidney take place during the physical effort - the blood pressure rises and its flow through the kidney falls (Poortmans, Vanderstraeten, 1994). These changes lead to disorders in the glomerular filtration and in mechanisms of the reabsorbtion which as a consequence influence the after effort blood content. The growth or the fall of the nitrogen compounds concentrations in the blood might be the reflection of physiological or pathological changes in the kidney. The estimated urea production rate during exercise suggests increased protein catabolism (Jansen et al., 1989; Portmans et al., 2001). The prolonged heavy exercise is accompanied by increased protein catabolism and changes in the plasma nitrogen compounds concentrations, similar to those observed during starvation, but differing from those seen at heavy exercise of less than 2 hours duration or prolonged exercise of moderate intensity (Refsum et al., cit. by Poortmans, Vanderstraeten, 1994).

There are numerous studies about exercise-induced sports proteinemia, hematuria, proteinuria, acute renal failure following marathon (Steward, Posen, 1980; Poortmans et al., 2001; Ayca et al., 2006). But studies investigating the effects of submaximal exercise on blood nitrogen indicators of renal function are quite few.

The aim of this study was to investigate the effects of submaximal veloergometric exercise on very important biochemical indicators of renal function - level nitrogen compounds (creatinine, urea, total protein) and uric acid (purine metabolite) in the blood.

\section{MATERIALS AND METHODS}

Subjects. The study was performed with 10 trained (Group 1), 10 untrained (Group 2) participants and 10 subjects with $\mathrm{I}^{\mathrm{O}}$ hypertensive status (Group 3). The age range was 20.5-21.3 years, weight $-71.8-77.3 \mathrm{~kg}$, height $-180-177 \mathrm{~cm}$.

Ten normotensive, healthy subjects of Group 1 were students, soccer players. The training of soc- 


\begin{tabular}{|c|c|c|c|c|c|c|c|c|}
\hline \multirow[b]{2}{*}{ Group } & \multirow[b]{2}{*}{$\mathrm{N}$} & \multirow[b]{2}{*}{ Age, years } & \multirow[b]{2}{*}{ Weight, kg } & \multirow[b]{2}{*}{ Height, cm } & \multirow[b]{2}{*}{ BMI, $\mathrm{kg} / \mathrm{m}^{2}$} & \multicolumn{2}{|c|}{ Blood pressure } & \multirow{5}{*}{$\begin{array}{l}\text { Table } 1 \text {. Physical } \\
\text { characteristics of } \\
\text { participants in } \\
\text { three groups (trai- } \\
\text { ned, untrained and } \\
I^{0} \text { hypertensive su- } \\
\text { bjects) }\end{array}$} \\
\hline & & & & & & $\begin{array}{l}\text { Systolic, } \\
\mathrm{mmHg}\end{array}$ & $\begin{array}{l}\text { Diastolic, } \\
\mathrm{mmHg}\end{array}$ & \\
\hline $\begin{array}{l}\text { Group } 1 \\
\text { Trained }\end{array}$ & 10 & $20.5 \pm 0.53$ & $72.42 \pm 4.94$ & $1.81 \pm 0.04$ & $22.1 \pm 1.08$ & $117.5 \pm 3.1$ & $83.10 \pm 2.24$ & \\
\hline $\begin{array}{l}\text { Group } 2 \\
\text { Untrained }\end{array}$ & 10 & $21.3 \pm 0.82$ & $71.8 \pm 4.13$ & $1.77 \pm 0.07$ & $22.94 \pm 1.62$ & $120.0 \pm 2.8$ & $90.0 \pm 2.18$ & \\
\hline $\begin{array}{l}\text { Group } 3 \\
\mathrm{I}^{\circ} \text { hypertensive } \\
\text { subjects }\end{array}$ & 10 & $20.7 \pm 0.67$ & $77.3 \pm 7.56$ & $1.80 \pm 0.04$ & $23.82 \pm 2.35$ & $158 \pm 3.5$ & $99 \pm 3.10$ & \\
\hline
\end{tabular}

Table 2. Nitrogen compounds concentrations in the blood of trained, untrained and $I^{\circ}$ hypertensive subjects before and after testing exercise (mean \pm standard error)

\begin{tabular}{|c|c|c|c|c|c|c|c|c|}
\hline \multirow[b]{2}{*}{ Group } & \multicolumn{4}{|l|}{ Before exercise } & \multicolumn{4}{|c|}{ After exercise } \\
\hline & $\begin{array}{l}\text { Creatinine, } \\
\mu \mathrm{mol} / \mathrm{l}\end{array}$ & $\begin{array}{l}\text { Urea, } \\
\text { mmol / } 1\end{array}$ & Protein, g / 1 & $\begin{array}{l}\text { Uric acid, } \\
\mu \mathrm{mol} / 1\end{array}$ & $\begin{array}{l}\text { Creatinine, } \\
\mu \mathrm{mol} / 1\end{array}$ & $\begin{array}{l}\text { Urea, } \\
\mathrm{mmol} / 1\end{array}$ & Protein, g / 1 & $\begin{array}{l}\text { Uric acid, } \\
\mu \mathrm{mol} / 1\end{array}$ \\
\hline Group 1 & $96.70 \pm 8.17$ & $6.18 \pm 0.66$ & $71.66 \pm 5.33$ & $192.40 \pm 38.59$ & $116.80 \pm 5.25$ & $7.48 \pm 0.71$ & $78.25 \pm 5.05$ & $220.60 \pm 38.30$ \\
\hline Group 2 & $96.60 \pm 9.69$ & $5.36 \pm 0.95$ & $69.41 \pm 4.02$ & $201.60 \pm 79.29$ & $100.10 \pm 9.72$ & $5.26 \pm 0.65$ & $71.21 \pm 4.27$ & $217.40 \pm 55.61$ \\
\hline Group 3 & $103.50 \pm 10.70$ & $6.36 \pm 1.37$ & $78.62 \pm 2.84$ & $217.40 \pm 55.61$ & - & - & - & - \\
\hline
\end{tabular}

cer players during the last week before the testing consisted of high-intensity training exercise (for 90 min) 2 days a week and moderate - intensity training once a week.

The subjects of Group $2(\mathrm{n}=10)$ were untrained students of Kaunas University of Medicine, who were involved in irregular physical activity.

The subjects of Group $3(n=10)$ were untrained young soldiers with symptoms of primary arterial hypertension.

Experimental protocols. Half an hour before exercise the antropometric values and blood pressure were measured. The blood was taken from the antecubital vein. Concentrations of creatinine, urea, total protein and uric acid in the blood serum were determined by using Technicon Auto Analyzer ADVIA 1650 system.

Testing Procedures. The incremental test was performed on a cycle ergometer (Monarc). The load consisted of pedaling at $60 \mathrm{rpm} / \mathrm{min}$. The participants were instructed and sat quietly for one minute on the ergometer before starting the exercise at $50 \mathrm{~W}$. The load was increased by $50 \mathrm{~W}$ every minute until maximal voluntary exhaustion was reached. Power and stroke rates were delivered continuously by computer display on the stacionary cycle ergometer. The test was designed to reach the maximum in approximately 7 minutes (mean load of $350 \pm 25 \mathrm{~W}$ ) with the subjects of Group 1 and 5 minutes $(250 \pm 13 \mathrm{~W})$ with the subjects of Group 2.

After the testing exercise the blood was also taken from antecubital vein for biochemical analysis.
The results were reported as the mean \pm standard error of the mean, and statistical significance was recognized when $\mathrm{p} \leq 0.05$.

The physical characteristics of the participants from all the three groups were shown in Table 1.

\section{RESULTS}

The blood nitrogen compounds mean results of trained, untrained and $\mathrm{I}^{\circ}$ hypertensive subjects were shown in Table 2.

As the results presented in Table 2 suggest, the pre-exercise blood concentrations of creatinine, urea, total protein and uric acid were markedly higher in subjects with $\mathrm{I}^{\circ}$ hypertension status (Group 3) compared to trained and untrained participants (Group 1 and Group 2), but concentrations of those blood parameters were higher in trained subjects (Group 1) compared with parameters of untrained subjects (Group 2).

The postexercise blood nitrogen compounds levels of trained participants (Group 1) were higher than the preexercise levels, and postexercise levels of trained subjects were markedly higher $(\mathrm{p}<0.05)$ than those of untrained (Group $2)$. However, before and after the exercise the increase of results in Group 1 and Group 2 was not statistically significant $(\mathrm{p}>0.05)$.

No statistically significant differences were observed between pre- and post-exercise blood creatinine, urea, total protein and uric acid levels comparing the mean results of the subjects in all groups (Table 2). But the results, presented in Table 3 , show a significant exercise induced increase in 


\begin{tabular}{|c|c|c|c|c|c|}
\hline \multirow{5}{*}{$\begin{array}{l}\text { Table } 3 \text {. Comparison of } \\
\text { significant differences in } \\
\text { mean values of blood ni- } \\
\text { trogen compounds inves- } \\
\text { tigated after the exercise } \\
\text { in subjects of Group } 1 \text { and } \\
\text { Group } 2\end{array}$} & Parameters & Stjudent $t$ test & $\begin{array}{l}\text { Significance of } \\
\text { differences }\end{array}$ & $\begin{array}{l}\text { Differences in } \\
\text { mean results }\end{array}$ & Standard error \\
\hline & Creatinine & 4.780108 & 0.00015 & 16.7 & 3.493645 \\
\hline & Urea & 7.312767 & 0.000000856 & 2.22 & 0.303579 \\
\hline & Total protein & 3.364807 & 0.00345 & 7.04 & 2.092245 \\
\hline & Uric acid & 0.581392 & 0.568186 & 16.1 & 27.69214 \\
\hline
\end{tabular}

\begin{tabular}{|c|c|c|c|c|c|}
\hline $\begin{array}{l}\text { Table 4. Comparison of } \\
\text { significant differences in }\end{array}$ & Parameters & Stjudent $t$ test & $\begin{array}{l}\text { Significance of } \\
\text { differences }\end{array}$ & $\begin{array}{l}\text { Differences in } \\
\text { mean results }\end{array}$ & Standard error \\
\hline trogen compounds before & Creatinine & 6.78069 & 0.00000237 & 16.6 & 2.448129 \\
\hline and after the exercise in & Urea & 3.85754 & 0.001154 & 1.401 & 0.363185 \\
\hline subjects of Group 1 and & Total protein & 4.420618 & 0.00033 & 4.79 & 1.083559 \\
\hline Group 2 & Uric acid & 5.442993 & 0.000036 & 25.3 & 4.648178 \\
\hline
\end{tabular}

blood creatinine and total protein levels were observed when we compared the results of trained and untrained participants only after the exercise.

Table 4 shows the significant $(\mathrm{p}<0.05)$ differences between exercise-induced increase in blood concentration of creatinine, urea, total protein and uric acid when we compared the results before the exercise with the values of those parameters after the exercise.

Our data showed that the results of blood nitrogen compounds before and after the exercise in Group 1 and Group 2 did not significantly differ comparing the differences in blood nitrogen compounds mean concentrations, but trained participants demonstrated markedly higher values $(\mathrm{p}<0.05)$ in post-testing exercises compared to the values of untrained participants. The differences in the levels of creatinine, urea, total protein and uric acid between the groups became larger when we compared the exercise intensity and load $(350 \pm 25 \mathrm{~W}$ in Group 1 and $250 \pm 13 \mathrm{~W}$ in Group 2). Although neither nitrogen compounds nor uric acid (purine metabolite) showed significant changes after the exercise, the more increased level of creatinine, urea and total protein in trained subjects compared with untrained participants' results could be related to greater total load of work in Group 1.

\section{DISCUSSION}

The hard exercise load and physical stress can induce muscle injury, kidney and liver damage (Cerny, Burton, 2001). Muscle injury associated with unaccustomed forceful eccentric contractions, which result in large efflux of protein into the blood, has caused kidney and liver failure (Cerny, Burton, 2001; Ehrman et al., 2003). Diagnosis of renal failure is typically made by determination of levels of serum creatinine, blood urea and other nitrogen compounds through blood test (Ehrman et al., 2003).

Physical exercise frequently induced acute hypertension and renal dysfunction is a high risk combination of overreaching and overtraining. An exercise which provides appropriate overload through manipulation of exercise intensity, duration and frequency becomes sufficient stress.

Physical exercise frequently is accompanied by increased protein catabolism and changes in the blood nitrogen compounds concentrations (Jansen et al., 1989; Hubner-Wozniak et al., 1996). It seems well established that proteins do not serve as a major fuel for energy production during physical exercise (Terjung, Tullson, 1992).

However, it has been clearly documented that strenuous exercise, in particular of prolonged duration, is accompanied by enhanced protein catabolism (Jansen et al., 1989) and several studies have been dedicated to increase the understanding of the significance of the nitrogen compounds metabolism during various types of exercise (Ayca et al., 2006).

Our data show that the comparison of preexercise and post-exercise values of blood nitrogen compounds concentrations in the participants of Group 1, 2 and 3 was accompanied by a marked increase in creatinine and urea concentrations, a moderate increase in total proteins and slight increase in uric acid levels. Together with the marked changes in the plasma nitrogen compounds pattern during exercise they add further support to the contention that enhanced protein and nitrogen compounds metabolism constitute an integral part of the metabolic response to exercise. The differences in metabolic response in the participants of Group 1 and Group 2 probably reflect differences in work intensity and volume. 
The deviant behaviour of the uric acid, showing unchanged or slight increased plasma concentrations at the end of exercise, are probably due to specific characteristics in their metabolism and bioenergy (Green, Fraser, 1988). Neither creatinine, nor urea are metabolized in muscles and their high levels in plasma and strikingly low concentrations in the postexercise urine show that these nitrogen compounds in particular are subject to the reduction of the renal excretory functions associated with heavy exercise (Poortmans et al., 2001).

Kidneys are highly active, because of the activity of epithelial cells of the proximal tubule, but decreased glomerular permeability or increased tubular reabsorption may increase the levels of blood nitrogen compounds. Therefore, blood nitrogen compounds is of great clinical interest as a marker for several renal disease (Poortmans, Vanderstraeten, 1994). When renal function changes, total protein and nitrogen compounds levels in the blood increase. Increased blood nitrogen compounds levels can be considered the indicator of proximal tubule function alteration (Ayca et al., 2006; Jansen et al., 1989). Postexercise increases were also detected in blood creatinine, urea, total protein and uric acid levels, while no change or decrease was observed in the clearance parameters. It is also known that the catecholamines released from the renal nerves can stimulate renin secretion by a $\beta$-adrenergic effect. This effect will enhance the responses of the renin-angiotensine system as reported by several authors during exercise (Zambraski, 1990). This observation rules out the potential action of catecholamines through the renin-angiotensin system and in the exercise induced hypertension of trained participants and subjects with $\mathrm{I}^{\circ}$ hypertension.

As our data showed there were no significant differences in the concentration of blood creati- nine, urea, total protein and uric acid in trained, untrained participants and the participants with $\mathrm{I}^{\circ}$ hypertensive status before the testing exercise. On the other hand, individual changes of nitrogen compounds in four trained participants, three untrained participants and six participants in the group of $\mathrm{I}^{\mathrm{O}}$ hypertension status occured as a moderate increase of those parameters before exercise and a marked increase after testing exercise in Group 1 and Group 2.

A significant exercise-induced increase in blood creatinine and total protein concentration was observed comparing the differences of trained and untrained participants after the exercise. A significant $(\mathrm{p}<0.05)$ exercise-induced increase in blood concentrations of urea and total protein was noticed comparing the values before the exercise and after the exercise.

\section{CONCLUSIONS}

1. The testing exercise-induced statistically insignificant $(p>0.05)$ increases in the blood parameters of nitrogen compounds (creatinine, urea, total protein and uric acid) could be due to the common phenomenon of the physical stress and catecholamine effects.

2. Postexercise changes of blood nitrogen compounds were significant $(p<0.05)$ when the results of Group 1 with Group 2 participants were compared. The significant differences in metabolic responce at Group 1 and Group 2 participants probably reflect differences in work volume and intensity.

3. Further studies are needed to be performed on more subjects to evaluate exercise-specific effects on postexercise changes of blood nitrogen compounds in athletes and nonathletes.

\section{REFERENCES}

Ayca, B., Sener, A., Apikoglurabus, S., Oba, R. (2006). The effect of exercise on urinary gamma-glutamyl transferase and protein levels of volleyball players. The Journal of Sports Medicine and Physical Fitness, Vol. 46, 4, $623-627$.

Bakonska-Pacon, E., Borkowski, J. (2003). The effect of the physical effort on the activity of brush border enzymes and lysosomal enzymes of nephron excreted in the urine. Biology of Sport, Vol. 20, 1, 69-77.

Cerny, F. Y., Burton, H. W. (2001). Exercise Physiology for Health Care Professionals. Human Kinetics.

Curtis, J. E., Russel, S. J. (1997). Physical Activity in Human Experience. Human Kinetics.

Ehrman, J. K., Gordon, P. M., Visich, P. S., Keteyian, S. J.
(2003). Clinical Exercise Physiology. Human Kinetics. Gore, C. J. (Editor) (2000). Physiological Tests for Elite Athletes. Australian Sports Comission. Human Kinetics.

Green, H. J., Fraser, I. G. (1988). Differencial effects of exercise intensity on serum uric acid concentration. Medicine and Science in Sports and Exercise, 20, 55-59.

Hübner-Wozniak, E., Lutoslawska, G., Sendecki, W. et al. (1996). Effects of a 10 week training on biochemical and hematological variables in recreational body builders. Biology of Sport, Vol. 13, 2, 105-110.

Ibsen, H., Olsen, M. H., Wachtell, K. et al. (2005). Reduction in albuminuria translates to reduction in cardiovascular events in hypertensive patients: Losartan intervention for endpoint reduction in hypertension study. Hypertension, 45, 198-202. 
Ibsen, H., Wachtell, K., Olsen, M. H. et al. (2004). Does albuminuria predict cardiovascular outcome on treatment with losartan versus atenolol in hypertension with left ventricular hypertrophy? A LIFE substudy. Journal of Hypertension, 22, 1805-1811.

Jansen, G. M. E., Degenaar, C. P., Menheere, P. P. C. A. et al. (1989). Plasma urea, creatinine, uric acid and total protein concentration before and after 15-, 25- and 42-km contests. International Journal of Sports Medicine, 10 (Suppl. 3), S 132-138.

Poortmans, J. R., Haggenmacher, C., Vanderstraeten, J. (2001). Postexercise proteinuria in humans and its adrenergic component. Journal of Sports Medicine and Physical Fitness, 41, 95-100.
Poortmans, J. R., Vanderstraeten, J. (1994). Kidney function during exercise in healthy and diseased humans. Sports Medicine, 18, 419-437.

Steward, P. J., Posen, G. A. (1980). Case report: Acute renal failure following a marathon. The Journal of Physiology and Sports Medicine, 8, 61-64.

Terjung, R. L., Tullson, P. C. (1992). Ammonia metabolism during exercise. In D. R. Lamb and C. V. Gisolfi (Eds.), Perspectives in Exercise Science and Sports Medicine, Vol. 5.

Zambraski, E. J. (1990). Renal regulations of fluid homeostasis during exercise. In C. V. Gisolfi, D. R. Lamb (Eds.), Perspectives in Exercise Science and Sport Medicine, Vol. 3, 247-280.

\title{
TRENIRUOTŲ IR NETRENIRUOTŲ ASMENU KRAUJO KREATININO, ŠLAPALO, BENDROJO BALTYMO IR ŠLAPIMO RŪGŠTIES KONCENTRACIJOS KITIMAS DE்L SUBMAKSIMALAUS FIZINIO KRŪVIO
}

\author{
Alina Gailiūniené ${ }^{1}$, Arvydas Stasiulis ${ }^{1}$, Jolanta Michailoviené $\dot{e}^{1,2}$ \\ Lietuvos kūno kultūros akademija ${ }^{1}$, Kauno medicinos universiteto klinikinè ligoniné $\dot{e}^{2}$, \\ Kaunas, Lietuva
}

\section{SANTRAUKA}

Literatūros šaltiniuose yra nemažai straipsnių apie sportininkų hematuriją, proteinuriją, ūmią inkstų pažeidą po maratono bėgimo (Steward, Posen, 1980; Poortmans et al., 2001; Ayca et al., 2006). Tačiau tyrimų, nagrinėjančiu kraujo azotinių medžiagu pokytị dèl fizinių krūvių, skelbta nedaug. Šio tyrimo tikslas - išsiaiškinti, kaip submaksimalus veloergometrinis krūvis veikia kraujo azotinių medžiagų rodiklius, labai svarbius inkstų funkcijos pažeidos diagnostikai.

Buvo tiriama 10 aktyviai sportuojančiu, 10 nesportuojančiu ir 10 tiriamujų kurioms nustatyti I ${ }^{\circ}$ hipertenzijos simptomai. Visi tyrimai atlikti atsižvelgiant ị Helsinkio deklaracijos nuorodas. Kreatinino, šlapalo, bendrojo baltymo ir šlapimo rūgšties koncentracija kraujo serume nustatyta naudojant Technicon Auto Analyzer ADVIA 1650 sistemą. Tyrimo duomenys ịvertinti statistinès analizès metodais, apskaičiuojant aritmetini vidurki, standartini nuokrypi, pakliovos intervalą, i̇vertinant Studento $t$ testą, skirtumo patikimumą ir standartinę paklaidą.

Lyginant visu triju grupių tiriamujų kreatinino, šlapalo, bendrojo baltymo ir šlapimo rūgšties koncentracijos kraujo serume vidurkių rodiklius, nustatytus prieš fizinį krūvị ir po jo, statistiškai patikimo skirtumo neaptikta. Pastebimas labai didelis kraujo azotinių medžiagų koncentracijos skirtumas po krūvio, lyginant treniruotų ir netreniruotų asmenų tyrimo rezultatų vidurkius.

Nustatytas ryškus $(\mathrm{p}<0,05)$ kraujo šlapalo ir bendrojo baltymo koncentracijos vidurkio didèjimo skirtumas, lyginant 1 ir 2-os tiriamuju grupès rezultatus.

Analizuojant atskirai individualų kraujo serumo azotinių medžiagų koncentracijos kitimą, sukeltą krūvio, nustatyta: po krūvio septynių 1-os grupes ir trijų 2-os grupès tiriamujų azotinių medžiagų koncentracijos rodikliai smarkiai peržengè fiziologinès normos ribas.

Atlikus tyrimą, galima daryti šias išvadas: 1) po submaksimalaus fizinio krūvio pastebima kraujo azotinių medžiagų koncentracijos didejjimo tendencija $(\mathrm{p}>0,05)$ rodo fizinio streso ir katecholaminų poveiki; 2) kraujo azotinių medžiagų koncentracijos po fizinio krūvio statistiškai reikšmingas $(p<0,05)$ skirtumas nustatytas lyginant 1 ir 2-os grupès tiriamujų rezultatų vidurkius (metabolinio atsako rodiklių reikšmingas skirtumas tarp 1 ir 2-os grupių tiriamujų galèjo priklausyti nuo darbo apimties ir intensyvumo); 3) norint ịvertinti, kaip konkretus fizinis darbas veikia kraujo azotinių komponentų koncentracijos kaitą, reikia atlikti daugiau tyrimu.

Raktažodžiai: kraujas, kreatininas, šlapalas, bendrasis baltymas, šlapimo rūgštis.

Gauta 2007 m. gegužès 15 d

Received on May 15, 2007

Priimta 2007 m. rugsèjo 19 d.

Accepted on September 19, 2007
Alina Gailiūnienè

Lithuanian Academy of Physical Education

(Lietuvos kūno kultūros akademija)

Sporto str. 6, LT-44221 Kaunas

Lithuania (Lietuva)

Tel +37037302671 